\title{
DETERMINANTS OF PASTORALISTS' CHOICE OF CAMEL PRODUCTION AND PRODUCTION SYSTEMS IN EASTERN ETHIOPIA
}

\author{
Abduselam ABDULAHI *1 (iD), Kibebew BABEGE ${ }^{2}$ (i) , Abreham ZUMA ${ }^{2}$ (D)
}

\author{
Address: \\ ${ }^{1}$ Kebri Dehar University, Department of Agricultural Economics and Agribusiness Management, Kebridahar, Ethiopia \\ ${ }^{2}$ Kebri Dehar University, Department of Animal Production and Technology, Kebridahar, Ethiopia \\ * Corresponding author: abdisalan654@mail.com
}

\begin{abstract}
This study aspires to identify determinants of pastoralists' choice of camel production and production systems in Korahay zone of Somali regional state, eastern Ethiopia. A cross sectional survey methods were applied to collect data from 158 sampled households in which 84 households were camel owners obtained through snowball sampling approach and remaining 74 households were non-camel owners obtained by using random sampling technique from three districts of Korahay zone in Somali regional state namely Kebridahar, Shelabo and Shekosh. The results of binary probit regression model revealed that socio-economic determinants including total livestock unit, farm income, non-farm income; herd size and distance from the nearest market were found to positively influence the likelihood of owning camels. Where, other determinants like age of the household head, household size and education level, dependent ratio, and distance from extension service were found to negatively influence the likelihood of owning camels. The overall regression model used indicated significant at $1 \%$ significance level $(\mathrm{p}=0.0013)$ which imply that all the supposed determinants jointly influenced the decision of pastoralists choice of camel production. In the study areas, majority of camel producer $(77.8 \%)$ rear camels for income generation, milking production, social and cultural functions. The three main production systems in the study areas were transhumant $(71.5 \%)$, sedentary system (19.6\%), and pastoral nomadic $(8.9 \%)$, which seems nomadism disappearing in the study areas. Feed shortage $(30.4 \%)$, drought and water shortage $(41.8 \%)$, disease prevalence $(18.3 \%)$, and market problems $(9.5 \%)$ are the major constraints of camel production in the study area. Majority of pastoralists in Korahay zone of Somali region (77.2\%) use extensive camel management system, and they cover long distance of around 12 to $18 \mathrm{~km}$ every day for grazing and browsing activities. In general, policy makers and government bodies should take in to consideration these variables determining the choice of camel production, and the current more pressing problems for pastoral communities such as drought and water shortage, lack of veterinary services, market problems, lack of enough capital for investment, and low access to credit services. It is strongly believed that consideration of these problems can enhance the life and livelihood of pastoral communities.
\end{abstract}

Keywords: Camel, Determinants, Livestock, Pastoralists, Production, Ethiopia JEL: C01; C13; D13; Q12; Q18

\section{INTRODUCTION}

Pastoralism is a culture, mode of production, in Africa especially in the horn whereby pastoralists depend on their livestock (Camel, Sheep and Goats, Cattle), they migrate seasonally due to rainfall and pasture availability. Many scholars defined pastoralism as proud livestock based production system, which is mainly extensive in nature (Hatfield and Davies, 2006; Mukherji et al., 2017).

Since the last three decades, pastoralism shows dramatic change in their socio-economic and livelihood systems which were triggered by interruption of wet and dry season grazing patterns, drought and change in land use and all these negative implications affecting livestock population and production Hartmann and Sugulle (2010). The changing contexts in which pastoralists operate raise the issue of sustainability of pastoral systems in Africa, particularly in the conflict-prone areas of the Horn of Africa.

In Sub-Saharan African countries, livestock are vital as a source of livelihoods and increasing future global demand for livestock and livestock products indicate greater opportunities for African livestock producers. Livestock production significantly contribute to the pastoralists' economy and is the major source of household wealth and supply end products that include milk, meat and hides and skins and used as transport. However, challenges of camel producers is very complex and complicated with policies and institutions related with the sector, this challenges are not technical (Too et al., 2015).

Livestock production makes significant contribution to the pastoral livelihoods, consumption commodity, household income and food security improvement. In the drylands of Ethiopia among other livestock types camel is a great asset recorded as avenue for life and livelihoods improvements. Since, camel is the only large mammal capable of inhabiting the arid lowlands, Somali pastoralists real extensively for their milk, meat, and transportation service and wealth status. Although Ethiopian pastoralists rear large number of camels, the official surveys estimate a total camel population in 
Ethiopia is most likely an under-estimate. The unique geographical, economic, social and cultural fabric of this biosphere is less known to the outside world even to many Ethiopians, as pastoralists were marginalized in the past (Tefera et al., 2013).

In fragile environments, camel contribute significant role for the improvement of pastoralists and agropastoralists live, as a drylands animal species it has an incomparable advantage compared with other livestock since it is the only livestock species capable of producing meat and milk when all other animals are limited by dehydration (Tura et al 2010; Simenew et al., 2013). Furthermore, most of its products are nutritious, healthy and have medicinal value. Under Ethiopian context, though the camel is an economically, socially and environmentally important animal, but among the least studied livestock species (Seifu, 2007; Tefera and Abebe, 2012). Camel is the most respected and prestigious animal species for pastoralist and agro-pastoralist communities. In economic value, camel fetches the highest price in livestock marketing and its value is equated to 44 heads of shoats (Badiye et al., 2011; and Bediye et al., 2018).

Currently, the estimation of camel population in Ethiopia was 4.5 million (LMP 2014; Shapiro et al., 2015) in which camel production of the Somali region pastoralists accounts for about 58 percent of the total country's camel population and the rest five pastoralists regions of the country account for 42 percent of the national camel herd. The camel is often regarded as symbolic of Somali people. For Somali pastoralists' camel is one of the basic indication and symbol of love, and status and wealth. Historically, camels were a valuable commodity used by the ruling classes and by the business community (Kumar, 1994). Despite Somali pastoralists has continuing emotional linkage with the camel; pastoralists in the region still involved in other animal husbandry like cattle, sheep and goats. Interviewed elders in the study area indicated, young individuals are not interested in keeping camel instead they seek wage labour in villages and urban areas. Camel is among least domestic animals, research on camel is a recent initiative and there are major gaps of knowledge and technology to improve overall productivity and pastoralist livelihood (Bediye et al., 2018). The scientific research in camel deals with basic science and technology transfer, its approach would make immense contribution to bring effective impacts on pastoralists' livelihood (Seifu, 2007). Besides the significances, research effort on camel in Ethiopia has also lagged behind other species and an urgent course of action is needed to benefit pastoralists and agro-pastoralists. The gaps in camel research can be bridged by strengthening and developing different research projects in pastoral setting to use modern production tools and techniques among the pastoralists. The future of camel producing pastoral societies in Somali region is debated by scientists, and pastoralist groups themselves. Therefore, this study is intended to assess the determinants of pastoralists' choice of camel production, and its impacts on pastoralists' livelihoods in the study area.

\section{DATA AND METHODS}

\section{Study area}

Somali regional state of Ethiopia is the second largest region of the country following Oromia region by having a land cover of 350,000 Kilometer Square. It has a border with Somalia, Djabouti and Kenya countries. Similarly, Somali region bordered with Afar and Oromia regions in West. Somali region has 93 districts and 11 zonal administrates in which Korahay is one of them. Korahay zone had in 2007 a total population of 312,713 , of whom 177,919 were men and 134,794 were women (CSA, 2007). The inhabitants of the Korahay are predominantly pastoralists. Korahay zone located at $1004.1 \mathrm{~km}$ from Addis Ababa the capital city of Ethiopia. The topography of the study area is predominantly lowland plain. Korahay zone climate characterized as tropical and semi-arid in which temperature ranges from 23 to $36^{\circ} \mathrm{C}$. The area has bimodal rainfall pattern with two main rainy seasons in which the first is ' $\mathrm{Gu}$ ' that occurs from mid-April to the end of June. The second rainy season known as 'Deyr' occurs from early October to late December.

In the Somali region, camel is a leading animal because of the multipurpose role it has on the provision of milk, meat, social and cultural importance besides unpaid transport service. This national survey (CSA, 2007) indicated that Korahay zone has 115,498 total number of camel and 5 number of camel per square kilometer which makes Korahay zone the second richest zone in camel production following Warder Zone of Somali regional state.

\section{Data collection technique and data sources}

Structured questionnaire combined with guided interviews were used to collect information from both camel owners and no-owners from selected three districts in Korahay zone namely Kebridahar, Shilabo and Sheygosh. Both primary and secondary data were collected from their respective sources. Camel owners obtained through snowball sampling approach and non-camel owners obtained by using random sampling technique since mobility, nature of access, under development of the infrastructure in pastoralists' areas make difficult to apply random sampling technique camel owners were selected based on camel possessions and willingness to be part of the survey.

\section{Sampling technique and sample size determination}

This study used multi-stage sampling technique to select the target districts and respondents. Districts within Korahay zone are stratified based on the estimated camel population, after stratification district with the highest camel populations are selected for consideration. The households of the selected districts are grouped into two important categories (With and without camels). The snowball-sampling technique was used due to rare and unknown of the households owning camels. To determine the sample size of the study formula developed by Saxena et al., (2010), specified in (Eq. 1).

$n=\left(z^{\wedge} 2 * p * q\right) / e^{\wedge} 2$ 
Where: $n$ is the required sample size, $z$ is 1.96 at $95 \%$ level of confidence, $p$ is 0.94 (which is approximately $94 \%$ and accommodates the margin of the households without camels in the study area) and $q=1-p$, i.e. 0.5 , and $e=0.05$ (which is the margin of error at $5 \%$ ). This gave a sample size of 86 households without camels. However, this value was lowered to match up the low sample size that emerged from the snowball sampling of camel herders so as to avoid sample size bias during analysis. Therefore, a total of 158 households are sampled out of which 84 owned camels while the 74 households were owned no camels.

\section{Method of data analysis}

This study used both descriptive statistical analysis and econometric models were applied to analyse the empirical data from this study. The primary data were processed in SPSS 20 and STATA 15. The descriptive statistics was used to describe the main characteristics of sample respondents. t-test and Chi-square tests were applied for testing differences between the camel owner and nonowner households of continuous and dummy variables respectively.

\section{Econometric model specification}

Econometric literatures give attention on regression models for dichotomous data, including logistic regression and probit analysis. These models are appropriate when the response takes one of only two possible values representing the presence or absence of an attribute of interest. The determinant of camel production is a binary choice in which we can use either logit or probit model analysis. This study will use probit model for estimating parameters of interest when the dependent variable is not fully observed. The probit model constrains the probability to $(0,1)$ interval and assumes that the probability that an event will occur is non-linear and that the random error terms follow a normal distribution.

The probability that an individual will choose to own camels depends on an underlying response variable that the expected utility from owning camels is greater than the utility of not. The random utility function ( $\left.y^{*}\right)$ for a herder in Korahay zone facing a decision to rear camels can be specified in Equation 2.

$Y i=1$ if $y *=i\left(x_{i} \beta+\mu\right)>0,0$ if otherwise

Where $Y$ is a dummy variable indicating household's ownership of camels $(1=$ if household owns camels, $0=$ otherwise $), \beta=\left(\beta_{0}, \beta_{1}, \beta_{2} \ldots \ldots \beta_{k}\right)$ is a vector of unknown parameters, $i$ is the choice of the practice, $x_{i}$ is a vector of covariates (explanatory variables), that is socio-economic and demographic characteristics of the individual, and $\mu$ is the error term.

The empirical model that determines the factors influencing herders' decisions to undertake camel production is specified in Equation 3. A household ( $i$ ) makes a decision to own camels $(Y)$ if the expected utility from camel ownership is positive. Household ownership of camels were associated with socio-economic and production characteristics that can be described as Eq. 3 .

$$
\mathrm{Y}_{\mathrm{i}}=\beta_{0}+\beta_{1 A g}+\beta_{2 S e x}+\beta_{3 H H S}+\beta_{4 O F I}+\beta_{5 F I}+
$$$$
\beta_{6 H S} \ldots \ldots \ldots \ldots \ldots \beta_{n X}+\mu
$$

Where;

Ag Age of the respondent;

Sex Sex of the respondent;

HHS Household size;

$E D L$ Education level of the respondent;

$O F I$ off-farm income;

FI Farm incomer;

HS Herd size;

$T L U$ Livestock holding unit;

$D E S$ Distance from extension service;

$D M P$ Distance from market place;

$D R$ Dependent ration.

Marginal Effects defined and calculated to determine how much each of independent variables changes the likelihood of respondents falling in the either category of dependent variables. It implies that how much a unit changes in the independent variable affect the likelihood of camel production, keeping all other variables at their mean values.

\section{RESULTS AND DISCUSSION}

\section{Summary of Descriptive and Inferential Statistics}

Survey data collected from total of 158 sample households in Korahey zone of Somali regional state, of which 84 households are camel owners and the remaining 74 households are non-camel owner households (Table 1).

The average age of sampled households was 39.44 in which the average age of the respondents from camel owner households was 38.91 years, whereas it is 40.29 years for the non-camel households, the age difference between the two groups was significant at $10 \%$ level of significance $(\mathrm{t}=0.911)$. This study contrary to that of Salamula et al., (2017) findings, that reported average age of camel owners as 54 whereas that of non-camel owners as 46 years.

Descriptive statistics (Table 1) reveal that in the study area $67.72 \%$ of the respondents were males and $32.28 \%$ were female. Camel owners were predominantly male $(43.67 \%)$ than female $(17.72 \%)$ in the study area. Based on the total sampled households and their respective answer on animal health accessibility in the study area, $65.82 \%$ in which $39.87 \%$ of them were camel owner households do not have access to animal health service, and $34.18 \%$ of sampled households have access to animal health service.

Average family size of sampled households was 7.78 and it indicate that the average family size of the respondents from camel owner households was 7.69, whereas it was 7.93 for the non-camel owner households, the average family size difference between the two groups was in-significant which means that there was no more difference between camel owners and non-owners in their household size.

As indicated in Table 1, the average year of schooling of sampled households was 3.63 and it was indicated that the average year of schooling of the respondents from camel owned households was 3.64 years, whereas it was 3.62 years for the non-camel owned households, the 
average year of schooling difference between the two groups was found to be in-significant.

Based on study result shown in Table 1, the average total livestock units of sampled households were 111.43 and the average total livestock units of the respondents from camel owned households was 146.48 , whereas it was 55.69 for the non-camel owned households, this imply that camel owned households have more total livestock units than non-camel owner in the study area which was highly significant $(\mathrm{t}=-12.445)$.

Descriptive statistic study results reveal that the difference between camel owners and non-owners in terms of their average annual income from off-farm and on-farm activities is statistically significant at $1 \%$ level of significance (Table 1). The mean income from off-farm activities for camel owner and non-camel owner households was ETB (Ethiopian Birr) 15530.93 (USD 531.966) and ETB 7562.42 (USD 259.028), respectively. The mean income from on-farm activities for camel owner and non-owner households is ETB 21496.39 (USD 736.296) and ETB 10463.92 (USD 358.411) respectively. The $\mathrm{t}$ test reveals that there is statistically significant difference in income generation from off-farm and onfarm activities at $1 \%$ probability level.

The quantity of milk and income from milk was estimated on the basis of the number of milking animals and the amount of milk that produced from cows, goats, sheep and camels and sold by the households. The descriptive result shows that there was significant difference between the two groups of households in that the mean annual income from milk production by camel owner and non-camel owner households was ETB 21496.39 (USD 736.296) and ETB 7220.574 (USD 247.319), respectively. The t test result reveals that there was statistically significant difference between the two groups at $1 \%$ significance level.

The proximity of households to the extension office and market center were analysed and the result showed that the average distances of camel owners and non-camel owners from extension office were $24.07 \mathrm{~km}$ and 22.65 $\mathrm{km}$ respectively, the difference between the two groups was significant at $10 \%$ level of the significance $(t=-1.379)$, while the average distance from nearest market center of the camel owner and non-owner households were 18.05 $\mathrm{km}$ and $11.34 \mathrm{~km}$, respectively, this is highly significant at $1 \%$ level of the significance with $t$ value of -4.168 .

\section{Camel Production and Feeding System}

Livestock production especially camel production plays important roles in cultural, economic and social development of Somali pastoral and agro-pastoral communities. Somali pastoralists are among marginalized communities in the country, stricken by recurrent droughts and the camel is usually the sole survivor. Camel herding for Somalis indicated as a basic way of life, insurance against natural disaster, wealth status, prestige, and highly valued cultural heritage. In Korahay zone of Somali regional state three main types of production systems for camel herds were adopted, in which $71.5 \%$ were transhumant and pastoralists with their livestock seasonally move from place to place for grazing, $19.6 \%$ were sedentary with resettlement and use mixed farming system, and only $8.9 \%$ of Korahay zone pastoralists use pastoral nomadic system in which livestock and owner move from place to place without permanent home, but pure nomadism seems to be disappearing in Korahay zone of Somali state (Table 2). To some extent pastoralists shifting to agriculture and original livestock production with resettlement. The transhumant movement of pastoralists resulted into peaceful associations the case of Turkana from the Kenya across the border of the neighbouring Karamoja (Hartley, 1984). Originally sedentary pastoralists dependent on agriculture and trade as their main economic activities but due to recent drought they shift to livestock rearing specially camels and small ruminants to compensate their losses in crops due to climate change.

Table 1: Summary statistics

\begin{tabular}{|c|c|c|c|c|}
\hline Variables & $\begin{array}{l}\text { Camel owned households } \\
\text { Mean } \pm \text { StD }\end{array}$ & $\begin{array}{l}\text { Non-camel households } \\
\text { Mean } \pm \text { StD }\end{array}$ & $\begin{array}{l}\text { Total households } \\
\text { Mean } \pm \text { StD }\end{array}$ & $\mathrm{X} 2 / \mathrm{Ch} 2$ \\
\hline Age (Years) & $38.91 \pm 10.21$ & $40.29 \pm 7.67$ & $39.44 \pm 9.31$ & $0.911 *$ \\
\hline Household size & $7.69 \pm 3.02$ & $7.93 \pm 2.79$ & $7.78 \pm 2.93$ & $0.307 \mathrm{NS}$ \\
\hline $\begin{array}{l}\text { Level of education } \\
\text { (year of schooling) }\end{array}$ & $3.64 \pm 4.25$ & $3.62 \pm 4.13$ & $3.63 \pm 4.19$ & $-0.038 \mathrm{NS}$ \\
\hline Total livestock unit & $146.48 \pm 50.43$ & $55.69 \pm 33.32$ & $111.43 \pm 62.81$ & $-12.445 * * *$ \\
\hline Off-farm income & $15530.93 \pm 9779.81$ & $7562.42 \pm 8465.96$ & $12454.48 \pm 10050.88$ & $-5.245 * * *$ \\
\hline On-farm income & $27408.25 \pm 14395.60$ & $10463.92 \pm 9992.61$ & $20866.45 \pm 15276.15$ & $-8.049 * * *$ \\
\hline Income from milk(Yearly) & $21496.39 \pm 12887.80$ & $7220.57 \pm 8692.04$ & $15984.84 \pm 13380.85$ & $-7.625 * * *$ \\
\hline Distance from extension office & $24.07 \pm 6.72$ & $22.65 \pm 5.49$ & $23.52 \pm 6.30$ & $-1.379 *$ \\
\hline Distance from nearest market & $18.05 \pm 9.78$ & $11.34 \pm 9.94$ & $15.46 \pm 10.34$ & $-4.168 * * *$ \\
\hline \multicolumn{5}{|l|}{ Sex } \\
\hline Male & $43.67 \%$ & $24.05 \%$ & $67.72 \%$ & 0.247 \\
\hline Female & $17.72 \%$ & $14.56 \%$ & $32.28 \%$ & \\
\hline \multicolumn{5}{|l|}{ Animal Health Access } \\
\hline Yes & $21.52 \%$ & $12.66 \%$ & $34.18 \%$ & 0.770 \\
\hline No & $39.87 \%$ & $25.95 \%$ & $65.82 \%$ & \\
\hline
\end{tabular}

Note: $*$ and $* * *$ mean significant at the $10 \%$ and $1 \%$ probability levels, respectively. 
Table 2: Herd Management and feeding system in Korahey zone, by districts

\begin{tabular}{|c|c|c|c|c|c|c|c|c|}
\hline \multirow[t]{3}{*}{ Variables } & \multicolumn{6}{|c|}{ District } & \multicolumn{2}{|l|}{ Total } \\
\hline & \multicolumn{2}{|c|}{ Kebri Dehar } & \multicolumn{2}{|l|}{ Shelabo } & \multicolumn{2}{|l|}{ Shekosh } & \multirow{2}{*}{ Freq. } & \multirow[b]{2}{*}{$\%$} \\
\hline & Freq. & $\%$ & Freq. & $\%$ & Freq. & $\%$ & & \\
\hline \multicolumn{9}{|l|}{ Production system } \\
\hline Pastoral nomadic & & 9.2 & 4 & 7.2 & 5 & 10.2 & 14 & 8.9 \\
\hline Transhumant & & 70.4 & 41 & 73.2 & 34 & 70.8 & 113 & 71.5 \\
\hline Sedentary & & 20.4 & 11 & 19.6 & 9 & 18.8 & 31 & 19.6 \\
\hline Total & & 100 & 56 & 100 & 48 & 100 & 158 & 100 \\
\hline \multicolumn{9}{|l|}{ Feeding system } \\
\hline Grazing and Browse spp. & & 87 & 51 & 91 & 24 & 50 & 122 & 77.2 \\
\hline Hay & & 9.3 & 3 & 5.4 & 18 & 37 & 26 & 16.5 \\
\hline Crop residues & & 3.7 & 2 & 3.6 & 6 & 12 & 10 & 6.3 \\
\hline Total & & 100 & 56 & 100 & 48 & 100 & 158 & 100 \\
\hline
\end{tabular}

Majority of pastoralists in Korahay zone of Somali region use extensive camel management system. This system is very common among camel breeders who rear small, medium to large camel herds. Pastoralists with their camels cover a long distance of around 12 to $18 \mathrm{~km}$ every day for grazing and browsing activities. This in line with the study of Wosene (1991), states that Ogaden pastoralists with their camels subjected to travel 14-20 km distance from their village in searching of feed and water. From the total sample $77.2 \%$ of pastoralists in Korahay zone use grazing and browsing feeding system, the remaining $16.5 \%$ and $6.3 \%$ use hay and crop residues feeding system respectively (Table 2). The results of this study in line with that of Mehari (2017) and Mirkena $\boldsymbol{e t}$ al., (2018), reported the major camel feeding systems were grazing and browsing at far distance.

The potential of irrigated pasture and its contribution to camel production substantiates the possibility of supporting intensive system of production in pastoral and agro-pastoral areas (Knoess, 1979). According to Aklilu and Catley (2011), intensive camel production system is recently observed in the mid altitude areas of Ethiopia which is the indication of the evolving mode of camel production system. In Korahay zone pastoralists use intensive production system to same extent $22.8 \%$ (Table 2) by keeping their animals around the town and villages especially in Kebridahar and Shekosh districts. This mode of production was also being experienced in Gode town (Sora, 2010).

\section{Purpose for Camel Production}

Camels are used as a reserve stock by Somali pastoralists since they are not frequently sold in the pastoral economy. From sampled households, $77.8 \%$ of the reason for camel production was for income source, social and cultural functions, and milking purpose (Table 3). This study is in line with the result of Elmi (1989), which indicated that Somali pastoralists in Ceeldher District of Somalia produce camel for milking and socio-cultural values. According to Hartley (1984), the main motivation for camel ownership in Turkana pastoralists is consistent provision of high quantities of milk by camels even in the dry season when cattle are moved to other locations in search for forage. For surprise, the result of this study shows that on average $6.65 \%$ of camel owned households produce camel for meat and wealth status (Saving).

Pastoralists in their nature prefer the status of having large herds to the money and goods that could be obtained by selling surplus animals. Camels are owned by both individuals and considered as communal properties. While camels are always considered as clan property for Somali pastoralists, when a family loses its animals, the individual owner has no absolute right to give or refuses to dispose of his camels, since it considered that camel belongs to all clan members. The results of this study indicate that about $27.8 \%$ of camel owner produce camel for social and cultural value in study area.

\section{Major Constraints of Camel Production}

Drought and water shortage, and feed shortage are the major constraints of camel production in Korahay zone of Somali region $(72.2 \%)$ and disease prevalence $(18.3 \%)$ and market problems $(9.5 \%)$ were the next principal constraints of the pastoralists for camel production (Table 4). Comparing the three sampled districts in Korahay zone, the study results reveal that Shekosh district has unique characteristics as compared with others by having high feed shortage problem $(45.8 \%)$ but there were no market problems. Even though, Afar and Somali pastoralists have the same environmental and socio-economic problems study by Simenew et al., (2013), found that disease prevalence as a production constraint in Afar region was $40.9 \%$, which is much higher than the result of this study. Camel herders and owners are increasingly facing feeding problems and water shortage in Gedarif State of Sudan, the amount of coverage of drinking water to the animal population in the state was about 50\% (Ayman, 2011).

Disease occurrence, shortage of feed and water are the major concerns for camel producers in Raya-Azabo (Abdisa $\boldsymbol{e t}$ al., 2017). Interviewed respondents stated that constraints to camel production in Korahay zone of Somali region included among others lack of enough capital for investment, lack of credit services, lack of access to animal health services, and security problems due to pasture based conflict between Somali clans (The case of Shelabo district). Therefore, these problems should get proper attention in addition to the current pressing problems of pastoralists like pasture, animal health services, and water shortages. 
Table 3: Purpose of Camel production in Korahey zone of Somali region, by districts

\begin{tabular}{|c|c|c|c|c|c|c|c|c|}
\hline \multirow[t]{3}{*}{ Variables } & \multicolumn{6}{|l|}{ District } & \multirow{2}{*}{\multicolumn{2}{|c|}{ Total }} \\
\hline & Kebri Dehar & & Shelabo & & Shekosh & & & \\
\hline & Freq. $\quad \%$ & & Freq. & $\%$ & Freq. & $\%$ & Freq. & $\%$ \\
\hline Income generation & 17 & 31.5 & 17 & 30.4 & 13 & 27.1 & 47 & 29.7 \\
\hline Meat production & 2 & 3.7 & 3 & 5.4 & 5 & 10.4 & 10 & 6.3 \\
\hline Milk production & 10 & 18.5 & 12 & 21.4 & 10 & 20.8 & 32 & 20.3 \\
\hline Sacrifices/rituals & 5 & 9.2 & 5 & 8.9 & 4 & 8.3 & 14 & 8.9 \\
\hline Social and cultural functions & 17 & 31.5 & 14 & 25 & 13 & 27.1 & 44 & 27.8 \\
\hline Wealth accumulation & 3 & 5.6 & 5 & 8.9 & 3 & 6.3 & 11 & 7.0 \\
\hline Total & 54 & 100 & 56 & 100 & 48 & 100 & 158 & 100 \\
\hline
\end{tabular}

Table 4: Major camel production constraints in Korahey zone of Somali region, by districts

\begin{tabular}{|c|c|c|c|c|c|c|c|c|}
\hline \multirow[t]{3}{*}{ Major constraint } & \multicolumn{6}{|l|}{ District } & \multirow{2}{*}{\multicolumn{2}{|c|}{ Total }} \\
\hline & \multicolumn{2}{|c|}{ Kebri Dehar } & \multicolumn{2}{|l|}{ Shelabo } & \multicolumn{2}{|l|}{ Shekosh } & & \\
\hline & Freq. & $\%$ & Freq. & $\%$ & Freq. & $\%$ & Freq. & $\%$ \\
\hline Feed shortage & 15 & 27.8 & 11 & 19.6 & 22 & 45.8 & 48 & 30.4 \\
\hline Drought and water shortage & 22 & 40.7 & 27 & 48.2 & 17 & 35.4 & 66 & 41.8 \\
\hline Disease prevalence & 11 & 20.4 & 9 & 16.1 & 9 & 18.8 & 29 & 18.3 \\
\hline Poor access to market & 6 & 11.1 & 9 & 16.1 & 0 & 0.0 & 15 & 9.5 \\
\hline Total & 54 & 100 & 56 & 100 & 48 & 100 & 158 & 100 \\
\hline
\end{tabular}

\section{Socio-economic determinants of camel production}

The results of this study revealed that socio-economic determinants namely total livestock unit, on-farm income, off-farm income; herd size and distance from the nearest market were found to positively influence the likelihood of owning camels in the study areas. Where, other determinants namely age of the household head, household size, and education level of the household head, dependent ratio and distance from extension service were found to negatively influence the likelihood of owning camels in the study areas. The overall probit regression model was significant at $1 \%$ significance level $(\mathrm{P}=$ 0.0013) indicating that all the espoused determinants jointly influenced the decision for camel production. According to Elmi (1989), environmental conditions, family needs, household size, milk requirements and labour availability for herding are the major determinants of camel production for pastoralists in Ceel-dheer, Somalia. Similarly, study by Martínez García et al., (2015), reported that age of the household heads, income sources and herd size were among the factors that influence adoption of animal husbandry technologies among farmers in Central Mexico. The results of these studies are in line with the current study result.

The age of the household head was significantly and negatively related to the probability of owning camels. This finding relates to the estimated mean age values for camel owner and camel non-owner households, where there was a lower average age for camel owners. The marginal effects indicated that if the age of the household increased by one unit, the change in the probability of a household owning camels decreased by $1.8 \%$. This study is in contrary to the study reported by Salamula et al., (2017), states age of the household head was positively and significantly correlated to the ownership of camels. Similarly, studies by Dossa et al., (2008) and KabuboMariara (2008) showed a connection between age and wealth particularly of livestock in pastoral production systems. The results of this study indicate that the nature of pastoralism came with structural changing and reform, elders resettle in to urban before their retirement age and young people left with livestock with full responsibility of production.

Household size was found to be significantly and negatively related to the probability of camel owning in the study area. Study result revealed that a unit increase in the household size by one person led to a decreased change in the probability of owning camels by very small percent.

Education level of the household head was found to be significantly and negatively related to the probability of camel owning. Study result revealed that a unit increase in the education level of the household head by one year led to a decreased change in the probability of owning camels by $2.7 \%$.

The results revealed that households that had larger livestock herds were more likely to own camels. Pastoralists attached with livestock for their socioeconomic and cultural value throughout their life. Increasing the total value of insured livestock and herd size by one unit increases the change in the likelihood of owning camels by $0.052 \%$ and $0.73 \%$, respectively. The result of this study is in line with that of Salamula $\boldsymbol{e t}$ al., (2017), which states that large livestock holding associated with camel ownership. Watson and Van Binsbergen (2008), Watson, Kochore and Dabassso (2016), Martínez García et al., (2015), results also revealed that large livestock holding is a sign of wealth among pastoralists and wealth often positively associated with new technology adoption which leads to livestock improvement. Camels are desert animals known for its resistant to harsh environment and produce milk during dry seasons and drought years when milk from other livestock species are scarce (Farah et al., 2004 and Salamula et al., 2017).

On-farm and Off-farm income were found to be a positive determinant of ownership of camels. The present results therefore suggest that the more income a household 
accrues from sale of livestock and their products, and receive extra income from other sectors households are more likely to own camels. A unit increase in the income from sale of farm produce and extra non-farm income would increase the change in the probability of owning camels by a very small extent.

Dependent ratio is ratio of age group those typically not in the labor force (age between 0 to 14 and 65+) and those typically economically active force (age group of 15 to 64). It is used to measure the effect of this ratio on camel ownership in the study area. The study finding revealed that dependent ratio negatively and significantly related with camel ownership. Therefore, a unit increase in the dependent ratio would decrease the change in the probability of owning camels by $1.5 \%$. Similarly, study by Salamula et al., (2017) revealed that, large households with presumably more dependents were less likely to own camels. Camels are very expensive to acquire, hence hindering financially constrained households.

Delivery of agricultural extension services and market accessibility for pastoralists were the two major concerns in pastoral development policies. Distance from nearest market and from nearest extension office were found to be positive and negative determinants of camel ownership respectively. The study result reveal that a unit increase in the distance from nearest market and from nearest extension office would increase/decrease the change in the probability of owning camels by $0.027 \%$ and $1.43 \%$ respectively. Study by Salamula et al., (2017), revealed that the majority of camel herders did not receive extension services as well as veterinary support, mainly due to the distant locations between the government offices and the households which is aggravated by the nomadic nature of the pastoralists.

The numbers in the parentheses are indicates robust standard error (Table 5). The estimated probit regression model in Table 5 suggests that, except distance from extension service, all other socio-economic determinant factors of camel production are found to be significantly positive/negative affecting the likelihood of camel production.

The result in Table 6 shows that to improve access to credit, information access should be improved, since almost all the farmers agreed that improved information access improves farmer's access to credit. Similarly, majority of the farmers see the availability of assets to be used as collateral as an important factor to farmer's access to credit. Apart from availability of assets for collateral, most crop farmers believed that reduced rigidity can serve as a means of improving access to credit to farmers. Also, a greater proportion of the farmers were of the opinion that if interest rates were subsidized, it will improve their access to credit.

Table 5: Determinants of camel production in Korahay zone of Somali region

\begin{tabular}{|c|c|c|}
\hline Determinants & Coefficients & Marginal effects \\
\hline Age & $\begin{array}{r}-0.030948 * * \\
(0.017215)\end{array}$ & -0.0185831 \\
\hline Household size & $\begin{array}{c}-0.027609 * \\
(0.0644718)\end{array}$ & -0.007657 \\
\hline Education level & $\begin{array}{c}-0.068180^{*} \\
(0.0431024)\end{array}$ & -0.0275221 \\
\hline Total livestock units & $\begin{array}{r}0.026477 * * * \\
(0.004265)\end{array}$ & 0.0073431 \\
\hline on-farm income & $\begin{array}{r}0.001362 * * * \\
(1.4 \mathrm{E}-05)\end{array}$ & 0.00001 \\
\hline off-farm income & $\begin{array}{r}0.002443 * * * \\
(2.1 \mathrm{E}-05)\end{array}$ & $1.5 \mathrm{E}-05$ \\
\hline Herd size & $\begin{array}{r}0.000816 * * * \\
(0.0034484)\end{array}$ & 0.0052264 \\
\hline Dependent ratio & $\begin{array}{c}-0.0575748^{*} \\
(0.1145846)\end{array}$ & -0.0159676 \\
\hline Distance from nearest market & $\begin{array}{c}0.010057 * * \\
(0.0317773)\end{array}$ & 0.0027892 \\
\hline Distance from extension service & $\begin{array}{r}-0.4884291 \\
(0.3784758)\end{array}$ & -0.1436827 \\
\hline _cons & $\begin{array}{r}-1.5851171 \\
(0.578723)\end{array}$ & \\
\hline $\begin{array}{l}\text { Number of obs. } \\
\text { LR chi2(10) }\end{array}$ & & $\begin{array}{r}158 \\
66.25\end{array}$ \\
\hline Prob > chi 2 & & 0.0000 \\
\hline Pseudo R2 & & 0.3143 \\
\hline Log likelihood & & -72.25686 \\
\hline
\end{tabular}

Note: $* * *$ and $* * *$ mean significant at the $10 \%, 5 \%$ and $1 \%$ probability levels, respectively. 


\section{CONCLUSION AND POLICY IMPLICATIONS}

The study results revealed that young individuals, less household members, high level of education, distance from extension services, and having more dependent household members, were less likely to take on camels in the study areas. The sign of age of household heads came up with interesting result since it contrary with the result of group discussion which indicated that young individuals are not interested in camel rearing instead they seek job in urban areas. But, the model result showed that young individuals were more likely to take on camel than older people. The study results also revealed that large livestock herd sizes, more income generated from livestock sales and products, more income generated from non-agricultural sectors, and having no access to market, were more likely to take on camels in Korahey zone of Somali sate. The descriptive results also revealed that drought, feed and water shortages, disease prevalence, and poor market access, were the major camel production constraints for pastoral communities. For improved camel production in Somali state especially Korahay zone, pastoralists should get training on camel production and management system. Attention should be given to the current pressing pastoralists' problems like feed and water shortage, young individuals should be encouraged in camel production by providing them financial support, and updated veterinary services and information system should be developed. Camel production is an important source of food security and livelihood diversification for pastoralists in Somali state of Ethiopia at present and near future. Therefore, the factors that positively influence camel ownership should be improved whereas special consideration should be given for those negatively influence camel ownership and their treatment.

\section{Acknowledgment}

The authors would like to thank Kebri Dehar University for logistic and financial support. The role of Interviewed pastoralists and local administrators in the study area is highly appreciated with thanks.

\section{REFERENCES}

ABBAS, B., AL QARAWI, A. A., \& AL-HAWAS, A. (2000). Enquête sur des élevges de dromadaires dans la région de Qassim en Arabie saoudite : stratégies de conduite, productivité et mortalité. Survey on camel husbandry in Qassim region, Saudi Arabia: Herding strategies, productivity and mortality. Revenue D'Livest Vet. Med. Trop. Countries (French), 53: 293-299. DOI: https://doi.org/10.19182/remvt.9727

ABDISA, T., WUBISHET, Z., \& ETSAY, K. (2017). Study on Major Constraints of Camel Production, Management and Their Impacts in and Around Yabello District, Oromia Regional State, Southern Ethiopia. Journal Dairy and Veterinary Science, 2017, Vol 3(1). DOI: $10.19080 / J D V S .2017 .03 .555604$

AKLILU, Y., and CATLEY A. (2011). Shifting Sands: The Commercialization of camel in mid altitude Ethiopia and beyond. Feinstein International Center, Tufts University.
AYMAN (2011). Production and management system of camel in Gadarif State, Eastern Sudan. Preliminary Study for Proposed Camel Milk Factory in Gadarif. Khartoum, Sudan.

BADIYE, S., TILAHUN, S., AMINUT, G., EIGE, M., and GETAHUN, G. (2011). Bridging Knowledge and Technology Gaps in Camel Production. Proceedings of International Conference on Camel Research and Development Held in Jigjiga, Ethiopia, October 27-29, 2011. pp.199-209. https://hdl.handle.net/123456789/2094 BADIYE, S., TILAHUN, S., and KIRUB, A. (2018). Engaging Opportunities for Camel Production.Ethiopian Somali Region Pastoral and Agro-pastoral Research Institute (ESoRPARI), Jigjiga, Ethiopia. Hand Book, ISBN: 9789994466474

CSA. CENTERAL STATISTICAL AGENCY (2007). Population and Housing Census Report. Ethiopia. Statistical Agency".Retrieved Nov 28, 2013(DoclReports\National_Statistical.pdf).

DOSSA, L.H., RISCHKOWSKY, B., BIRNER, R., \& WOLLNY, C. (2008). Socio-economic determinants of keeping goats and sheep by rural people in southern Benin. Agriculture and Human Values 25 (4): 581-592 DOI: https://doi.org/10.1007/s10460-008-9138-9

ELMI, A. A. (1989). Camel Husbandry and Management by Ceeldheer Pastoralists in Central Somalia. Somali Government and USAID project. ISSN 0951-1911

FARAH, K. O., NYARIKI, D. M., NGUGI, R. K., NOOR, I. M., \& GULIYE, A. Y. (2004). The Somali and the camel: Ecology, management and economics. Anthropologist $6 \quad$ (1): 45-55. DOI: https://doi.org/10.1080/09720073.2004.11890828

HARTLEY, B.J. (1984). The dromedary of the Horn of Africa. In: Cockrill, W.R. (Ed.). The Camelid - An Allpurpose Animal, Proceedings of Khartoum Workshop on camels, December 1979. 1:77-79. Uppsala: Scandinavian Institute of African Studies.

HARTMANN, I., \& SUGULLE, A. J., (2010). The Impact of Climate Change on Pastoral Societies in Somaliland. Case report, p:62. https://www.preventionweb.net/go/13863

HATFIELD, R., \& DAVIES, J. (2006). Global review of the economics of pastoralism. Prepared for the World Initiative for Sustainable Pastoralism, IUCN: Nairobi

ILMI (1989). Camel Husbandry and Management by Ceeldheer Pastoralists in Central Somalia. Botany and Range Science Department Faculty of Agriculture, Somali National University, PO Box 801, Mogadishu, Somalia. KABUBO-MARIARA, J. (2008). Climate change adaptation and livestock activity choices in Kenya: An economic analysis. Natural Resources Forum 32:131-141. DOI: https://doi.org/10.1111/j.1477-8947.2008.00178.x

KNOESS, K. H. (1979). Milk production of the dromedary. In: IFS Symposium Camels. Sudan. pp: 201214.

KUMAR, V. S., (1994). The Rathore Rajput Hero of Rajasthan: Some Reflections on John Smith's The Epic of Pabuji. Modern Asian Studies. Vol. 28 (3), pp. 589-614, DOI: https://www.jstor.org/stable/313045

LMP. Livestock Master Plan. (2014). Roadmaps for growth and Transformation developed by livestock team for the ministry of agriculture livestock resources 
development sector, Addis Ababa, Ethiopia. MARTÍNEZ-GARCÍA， C. G., DORWARD, P. \& REHMAN, T. (2015). Factors Influencing Adoption of Crop and Forage Related and Animal Husbandry technologies by Small-Scale Dairy Farmers in Central Mexico. Expl Agric. (2016), volume 52 (1), pp. 87-109. Cambridge University Press. DOI: https://doi.org/10.1017/S001447971400057X

MEHARI, Y. (2017). The Status and Major Constraints of Camel Production in Ethiopia. LAP LAMBERT Academic Publishing. 136 pages. ISBN-10: 3659959529 MIRKENA, T., WALELIGN, E., TEWOLDE, N., GARI, G., ABEBE G., \& NEWMAN, S. (2018). Camel production systems in Ethiopia: a review of literature with notes on MERS-CoV risk factors. Pastoralism 8, 30 (2018). https://doi.org/10.1186/s13570-018-0135-3 MUKHERJI, G.B., RAO, J., CHATURVEDI, R., \& PRIYADARSHINI, P. (2017). Evolving a Policy on Pastoralism in the Semi-arid State of Rajasthan, and India. Annual World Bank Conference on Land and Poverty. Washington DC, March 20-24, 2017.

SALAMULA, J. B., EGERU, A., ASIIMWE, R., ALEPER, D. K. \& NAMAALWA, J. J. (2017). Socioeconomic determinants of pastoralists' choice of camel production in Karamoja sub-region, Uganda. Pastoralism 7, 26 (2017). DOI: https://doi.org/10.1186/s13570-017-0096-y

SEIFU, E. (2007). Past, Present and Future Perspectives of Animal Sciences. Ethiopian Journal of Animal Production 5(1), pp:49-75.

SAXENA, S., GAUTAM, S., \& SHARMA, A., (2010). Physical, biochemical and antioxidant properties of some Indian honeys. Food Chemistry 118(2):391-397. DOI: https://doi.org/10.1016/j.foodchem.2009.05.001

SHAPIRO, B. I., GEBRU, G., DESTA, S., NEGASSA, A., NEGUSSIE, K., ABOSET, G. \& MECHAL, H. (2015). Ethiopia livestock master plan: Roadmaps for growth and transformation, A Contribution to the Growth and Transformation Plan II (2015-2020); Ministry of Agriculture Livestock Resources Development: Addis Ababa, Ethiopia.
SIMENEW, K., DEJEN, T., TESFAYE, S., FEKADU, R., \& FUFA, D., (2013). Characterization of Camel Production System in Afar Pastoralists, North East Ethiopia. Asian Journal of Agricultural Sciences 5(2): 1624, 2013. DOI: https://doi.org/10.19026/ajas.5.2579

SORA ADI. (2010). Conference report. Proceedings of the 5th national conference on pastoral development in Ethiopia. pp.15-86.

TEFERA, M., \& ABEBE, G. (eds.), (2013). Camel in Ethiopia 2012. Ethiopian Veterinary Association: Addis Ababa. ISBN 9789994498192

TOO, R., MASAKE, R., OYOKO, G., \& ONYANGO, D. (2015). The Contribution of Livestock to Somalia Economy. VEDAMAN Consultants Limited, Nairobi, Kenya. IGAD Centre for Pastoral Areas and Livestock Development (ICPALD). pp.33

TURA, I., KURIA, S. G., WALAGA, H. K., \& LESUPER, J. (2010). Camel Breeding Management among the Somali, Sakuye, Gabbra and Rendille Pastoralists of Northern Kenya. Tropentag, Zurich.

WATSON, D. J., \& VAN BINSBERGEN, J. (2008). Livelihood diversification opportunities for pastoralists in Turkana, Kenya, ILRI Research Report 5, ILRI, Nairobi, Kenya.

WATSON, E. E., KOCHORE, H. H., \& DABASSO, B. H. (2016). Camels and Climate Resilience: Adaptation in Northern Kenya. Hum Ecol 44, 701-713 (2016). DOI: https://doi.org/10.1007/s10745-016-9858-1

WOSENE, A., (1991). Traditional Husbandry Practices and Major Health Problems of Camels in the Ogaden (Ethiopia). Nomadic peoples: Camel Pastoralism in the Horn of Africa.No.29, pp: 21-30 